\title{
Training of innovative engineers for problems of modernization of a domestic production
}

\author{
I. Brusakova ${ }^{1}, A . Z_{\text {vontsov }}{ }^{1}$, and $O$. Shvetsova $^{1, *}$ \\ ${ }^{1}$ Faculty of economics and management, Saint-Petersburg State Electrotechnical University (LETI), Saint-Petersburg, Russia DP \\ Sciences
}

\begin{abstract}
The actual problem of training of innovative managers for problems of modernization of a domestic production is considered in research. Practice of application of innovative engineering in the sphere of modernization of industrial productions is studied. The perspective of an integrated approach to management of innovative processes is investigated, including competence-based approach to training of innovative managers and modern instruments of management of finance innovative business - processes. Authors offered new approaches to formation of innovative capacity of the domestic industrial enterprises. Different ways of innovation creation are discussing.
\end{abstract}

\section{Introduction}

At the present stage of social and economic development of Russia it is necessary to realize modernization of domestic knowledge-intensive production. Preparation of engineering shots by the leading technical colleges of Russia is carried out with use of new federal state educational standards of the third generation (FGES 3+). Orientation to professional engineering competences which are defined by the employer - distinctive feature of the materials FGES3+. Existence of the international educational standards of engineering education (CDIO) allows to consider need of creation of infrastructure of engineering education as a condition of efficiency of formation of educational services for engineers.

\section{Concept of innovative engineering}

University of "LETI" as the innovative higher education institution participating in the TOP program 100 improves educational infrastructure [1]. Application of innovative forms of conducting educational activity (continuous, remote formation, use of innovative educational technologies on the platform e-learning, Learning Space, science and technology park, the small innovative enterprises, the research centers in structure of LETI, the organization of close interrelation in a framework of strategic partnership University of "LETI" with the leading manufacturing enterprises of $\mathrm{SPb}-$ allows to position University of "LETI" as the innovative higher education institution capable to organize preparation of engineering shots for problems of domestic economy.

Current trends of innovative development of the country are caused by need of introduction of ideas of innovative engineering for the organization of production of innovative production. The term "innovative engineering" is entered by O. L. Figovsky [2]. The author connects contents of the term with need of creation of an innovative product with use of innovative infrastructure of production. Any product, new to the market, is made with use of the R\&D technology, i.e. is result of use of a successful combination of all resources, necessary for his production, - human, logistic, material, production, financial, information, monetary, etc. Transition to production of new innovative products in the "digital" enterprise, use of the CLOUD, SMART, GREEN, GRID technologies - communications - an important component of the modern infocommunication technologies allowing to provide "new properties" to the made product.

The innovative engineer, the engineer innovator has to be trained for realization of all stages of life cycle of innovative processes and projects in new technological way - from market researches of a commodity market and services before design and operation of innovative goods or service, carrying out patenting, commercialization and advance on the market. Skills of the innovative engineer are directly used for the organization of effective activity of the digital enterprise [3].

\section{Model of competences of the innovative manager}

Important role in innovative engineering in business increase of effective management of a human resource is taken away.

Rational management of innovative processes is possible in the presence of the developed motivational system which is created on purpose: 
- initiations of innovative activity of employees;

- adequate assessment of results of innovative activity of managers and experts of various level and their subsequent encouragement;

- strengthenings of communication communications between divisions of the company;

- integration of innovative activity of staff of various divisions into market success.

The effective motivational innovative system has to cover all levels of management: top-management, average management, experts, working and technicians.

The leading role in formation of innovative climate at the enterprise belongs to top-management. "Ideas then seize the masses when they seize the heads of the first heads" [4].

Key to success - in the head of the innovative project which is appointed not so much for ability to the solution of scientific and technical tasks how many and it is more important, for the qualities of the head and businessman.

Practice has developed a number of requirements to the head of the innovative project. It is necessary for the head for success:

- to possess abilities to think in a complex;

- to be able to operate people and to be able to operate itself;

- to be able to interact with the management;

- to be provident;

- to be capable to maintain stresses, to be an optimist;

- to have perspective business thinking;

- to be able to transfer information;

- to operate effectively time.

The model of the effective innovative manager assumes presence at him of cognitive and functional competence $[5,6]$.

Cognitive competence.

The innovative manager has to know

- concepts, methods of innovative management;

- content of innovative strategy and policy, instruments of their formation and realization at the enterprise;

- methods of an assessment of level of innovative development of the enterprise;

- bases of the organization of innovative infrastructure;

- methods of search of new ideas and technical decisions;

- standards and methods of ensuring quality and competitiveness of innovations;

- technologies of protection of intellectual property at the enterprise.

Functional competence.

These are skills and abilities of development and realization of innovative strategy and policy, technologies and methods of work in functional spheres of innovative management taking into account conditions and specifics of the concrete organization.

The innovative manager has to be able:

- to develop innovative strategy and policy at the enterprise;

- to organize innovative process at the enterprise according to methodology of system approach to management of innovations;

- to form creative group of developers of an innovation, to diagnose a condition of group, to stimulate creative activity;
- to apply methods of search of new ideas and technical solutions;

- to be able to make the business plan of the project;

- to be able to estimate market appeal of an innovation and its competitiveness;

- to own methods of commercialization of innovations;

- to own methods of planning of innovative process;

- to own methods of an assessment and protection of intellectual property;

- to possess skills of search and work with information on achievements in the special innovative sphere.

In a portfolio of innovative projects of the company there have to be projects of various level:

- projects on development of essentially new products and technologies providing innovative leadership;

- several projects maintaining competitiveness of the existing commodity policy: on expansion of a grocery ruler, modernization, improvement of quality, etc.;

- programs and projects on support of innovative activity of employees [6].

Conveniently and effectively to operate realization of innovative strategy of the enterprise within system of management of projects with use of modern instruments of management.

Tactical aspects of innovative development are realized in the form of involvement of workers in innovative activity: promotions of ideas, improvement suggestions on improvement of technical processes, improvement of quality of production, prime cost reduction, etc.

It is possible to present universal model of competences of the innovative manager:

To specify within what program or a grant work or sponsors was performed.

In case of lack of the similar reference - to remove this text field

1. Universal (it is general administrative) competences

Basic administrative competences:

- ability to analyze a market situation, to reveal, formulate and range problems;

- skills of statement are more whole, preparation and adoption of administrative decisions;

- ability to concrete system of the purposes, to formulate tasks and to prove the choice of ways and methods of their decision.

2. Interpersonal competences:

- ability to form team and is effective in it to work;

- existence and development of leadership skills;

- skills of the presentation and negotiating.

3. Tool competences:

- linguistic - ability to use language means for the solution of professional tasks;

- information - ability to prove the choice and to use modern information products and technologies for the solution of objectives.

4. Subject and specialized competences:

- ability to carry out the marketing and strategic analysis of the organization, to make the ranged list of prospects of development and risks;

- ability to prove the priority directions of innovative development and to form innovative strategy, programs and projects of the enterprise (organization); 
- ability to carry out complex diagnostics of the organization, the analysis of her financial and economic state and to develop strategies of financing of innovative development;

- ability to estimate the economic potential of an innovation, to carry out the feasibility study on innovative projects and programs;

- ability to find (to choose) optimal solutions during creation of new knowledge-intensive production taking into account requirements of quality, cost, dates of performance, competitiveness and economic efficiency; - ability to put and solve organizational tasks, to carry out scheduling of implementation of innovative programs and projects.

The sphere of innovative activity of employees, her activization has high potential of innovative development of the company. Formation at the enterprise of complete organizational and motivational system of mobilization of creative potential of workers on the solution of tasks of increase of competitiveness of business is for this purpose expedient.

Within motivational innovative system the mechanism of an assessment of efficiency of intra company innovations for each division (research and development, production, sale, logistics, marketing, management, finance, shots, etc.) with definition of criteria, indicators of methods of an assessment, forms and methods of encouragement has to be created.

\section{Financial management of innovative processes}

The rational management of finance of the enterprise, automation of the administrative reporting, opportunity to quickly monitor the movement and target use of money allow to plan and predict development of the company, to make reasonable administrative decisions. Management of finance of the enterprises is a management in the sphere of the monetary relations concerning formation, distributions and use of the monetary income, accumulation and financial resources for the purpose of their most effective use and increase of solvency of the enterprise. The main objective of financial management on mobilization and use of monetary funds of the enterprises consists in maximizing their real liabilities and assets [8]. At the same time the following questions of financial management are essential:

- planning and forecasting of financial activity. Financial services of the enterprises develop financial plans which represent forecasts of output and product sales, development of scientific and technical progress, introduction of new administrative decisions and providing them with financial resources;

- adoption of the most expedient decisions in process of investment of means;

- coordination of financial activity with all services of the enterprises. For example, decisions in the field of marketing influence realization volume that, in the turn, makes impact on the size of profit and investments;
- carrying out operations in the financial market on mobilization of the additional capitals, implementation of own stocks and bonds.

Planning takes the central place in management of finance. This results from the fact that when planning the condition of finance of this or that subject of managing is comprehensively estimated, possibilities of increase in financial resources, the directions of their more effective use come to light. The relevant administrative decisions in the course of planning are accepted on the basis of the analysis of financial information which has to be rather full and reliable. The financial plan has to be full financial display of all planned activity of the enterprise. It defines an integrated approach to development of the system of financial planning: she has to cover all basic structural elements of the enterprise and all essential stages of the processes going to them.

Operational management represents a complex of the actions developed on the basis of the operational analysis of the developing current financial situation; their purpose - receiving the maximum effect of redistribution of financial resources at a minimum of expenses. The main content of operational management consists in maneuvering by financial resources for the sake of timely performance of necessary actions, and also elimination of possible difficulties on separate sites of financial and economic activity of the enterprises. Reserve funds, superplanned financial resources, the credits of banks, etc. can be sources of such maneuvering.

Control as an element of management is carried out both at a planning stage, and at a stage of operational management. He is urged to provide full and timely receipt of money in the centralized and decentralized funds of financial resources, finishing them to the recipient, economical and target use.

At diagnostics of the existing control system of finance at the enterprise, first of all, it is estimated how administrative reporting reflects an economic condition of the company how existing technique of management corresponds to tasks of the enterprise, and are how automated management processes. As a result of the analysis of the existing control system of finance, it is necessary to develop the outline sketch which includes ideal model of work of the enterprise. It is obvious that it is almost impossible to implement the similar project therefore it is necessary to finish it taking into account realities of work of the enterprise. Quite often improvement of management of finance can "bury" in equipment of the company necessary equipment or lack of the software, lack of money on introduction of the ideal project, and also in the low level of preparation of personnel of the company.

Proceeding from realities of work of the company, more "grounded" document including the list of organizational actions which have to be realized at the enterprise is developed. Besides, necessary normative documents are developed, business processes are described, and also modification of the existing automated system is made. Automation of finance - the most up-to-date tendency in management, both the enterprises in general, and finance in particular. The 
automated system is the main step to effective management and development of business [9]. Automation of business is necessary first of all for dynamically developing organizations which seek to take the leading positions in the market. Automated control systems for finance of the enterprise serve as the tool for obtaining competitive advantage before other organizations.

The automated financial systems at the enterprises will allow heads of an average and the top management to obtain operational information about financial and economic activity of the enterprise, to control the income and expenses, it is essential to raise the profit, to increase sales, to successfully realize investment projects. Owing to what competitiveness and investment appeal of the enterprise will increase, the probability of monetary frauds at the enterprises decreases.

Management of process of functioning and organizational structure within which this process is carried out have significant effect on productivity of production and commercial activity of any enterprise. Correctly chosen structure allows to provide to the enterprise or the company a full employment of personnel, flexibility in use of resources and compliance to requirements of the market. Thus, we inevitably come to need of bigger or smaller reorganization of a control system of innovative activity of the enterprise. For adoption of reasonable and operational decisions the management needs often to count and compare several versions of plans in short terms. Thus, innovations are not only use of high technologies, but also innovations in the sphere of administrative decisions.

Reorganization of system of business management on the basis of new administrative technologies is necessary for realization of the majority of the tasks facing the enterprise. The enterprise intending to work flexibly inevitably comes to need of use of innovative approaches. For a significant amount of the large industrial enterprises, improvement of a control system of finance means, in that number, financial reforming and restructuring. Structural transformations are based on economically reasonable strategy of reforming. According to her the system of financial management by the enterprise as system of planning, the account and control of the enterprise in the course of his financial reforming and restructuring is also developed.

It is necessary to develop system of management of innovative activity which basis - splitting difficult process into simple components on the basis of design approach and forming of peculiar administrative "conveyor" for effective realization of the tasks facing the enterprise. It gives a number of effects: work from process turns into the purposeful movement, labor productivity sharply increases, the quantity of mistakes decreases. It is necessary to develop effective organizational structure, a control system of finance for realization of such approach, to create service of marketing, to provide document flow, i.e. in details to formulate rules of work of the enterprise, in the main the general for all companies of an innovative orientation $[5,6]$.

\section{Conclusion}

It is possible to draw the following conclusion: it is necessary to project innovative development of the enterprise in the same way, as well as any system. It is necessary not only define the tasks facing the enterprise but also to create the system providing transition of the enterprise to this state, to define necessary resources, to develop business processes of innovative activity. Only this way it is possible to count on success.

Substantial basis of the system of financial management of the industrial enterprise which is adequately considering the level of influence and ways to avoid financial risks, is budgeting. The management of cash flows of difficult economic complexes what the industrial enterprises are, can't but use schemes of behavioral modeling of possible results of the movement of monetary resources. Development of financial models of an assessment and management of financial risks is a part of the general system of budgeting at the enterprise. They are rather reliable tool of an assessment and management of all system of financial risks at the enterprise as allow to weigh different levels of risks in connection with various factors of impact on them and controllability levels them.

In general, the control system of finance of the enterprise has to provide for the management transparency of a financial state and the movement of financial resources, formation of the most favorable versions of financial plans, the operational accounting of the actual information, control of a deviation from the plan. In this regard, a basis of a control system of finance at the enterprise are: the coordinated analysis of material streams and financial streams, as on separate commodity groups and divisions, and on the enterprise in general; a combination of planning and control of implementation of plans on the basis of coordination of planned documents with system of accounting and the reporting. It gives the chance of formation of the coordinated financial plans both for the enterprise in general, and on his divisions and activities. The created control system of finance of the enterprise has to give the chance to solve the following problems of management of finance:

- assessment of a financial condition of the enterprise; - a financial assessment of the main directions of activity (expenses, profit, profitability and other indicators on commodity groups, divisions, contractors);

- the choice of the most profitable option of assortment policy (structure of the range and sales volumes on his positions);

- formation of budgets of divisions and control of their performance;

- planning and control of financial streams; 
- check of financial feasibility of sales plans and plans of purchases;

- the forecast and prevention of bankruptcy and a swagger - major situations;

- determination of terms, volumes and expediency of capture of the credits;

- analysis, planning and control of profits and losses;

- analysis, planning and control of change of structure of balance (structure of the capital, etc.)

As a result of improvement of a control system of finance at the enterprise, management of manufacturing enterprise has to have more opportunities for adoption of business solutions, the reporting of the enterprise has to become more transparent for investors and shareholders that will allow to increase efficiency of work and investment appeal of the innovative company.

The integrated approach to formation of actual model of management of innovative engineering allows to reconsider modern practice of training of experts, including taking into account the international standards and to develop logically proceeding business processes in the field of financial and information management that allows to transform productions of the domestic enterprises according to actual economic and political realities and to carry out modernization of key resources.

\section{References}

1. A.V. Zvontsov, Proc. Modern education: contents, technologies, quality, 62-63 (2003)

2. V.M. Kutuzov, S.O. Shaposhnikov, O.A. Shvetsova, Proc. Planning and Ensuring Training for an Industrial and Economic Complex of the Region, 125-136 (2015)

3. O.A. Shvetsova, Innovative aspects of human resource management in business (St. Petersburg, 2012)

4. I. Brusakova, Proc. of XIX Int. Conf. Systems Analysis in Desier and Management, 2, 16-22 (2015)

5. T.A. Khudyakova, Proceedings of the International Congress on Interdisciplinary Behavior and Social Science, 295-297 (2015)

6. T.A. Khudyakova, A.V. Shmidt, Proc. of The 26th International Business Information
Management Association Conference, 1617-1625 (2015)

7. O.A. Shvetsova, Proc. Innovation Management and Sustainable Economic Competitive Advantage: From Regional Development to Global Growth: Proceedings of The 26th International Business Information Management Association Conference, 1619-1628 (2015)

8. GOST $R$ 56407-2015, Lean production: main methods and instruments

9. E. Mach, Erkenntniss und Irrtum (Reidel Publ., 1976)

10. R. Mayer, M. Painter, C. Menzel, B. Perakath, P. deWitte, T. Blinn, Knowledge Based Systems Publ. (1995)

11. National Institute of Standards and Technology Integration definition for function modeling (IDEF0), (1993)

12. Ching-Hong Tsai, How-Jen Luo, Feng-Jian Wang, Proc. 11th IEEE International Workshop on Future Trends of Distributed Computing Systems, (2007). DOI: 10.1109/FTDCS.2007.17.

13. R. Braun, Proc. 2015 IEEE 17th Conference on Business Informatics (CBI), (2015). DOI: 10.1109/CBI.2015.41.

14. S. Yamasathien, Proc. 2014 Fourth International Conference on Digital Information and Communication Technology and it's Applications (DICTAP), (2014). DOI: 10.1109/DICTAP.2014.6821684

15. M. Chinosi, A. Trombetta, IEEE Conference on Commerce and Enterprise Computing, IEEE Publ., (2009). DOI: 10.1109/CEC.2009.48

16. A.H. Maslow, Psychological Review, 50(4), 370396 (1943)

17. A.H. Maslow, Motivation and personality (Harper \& Row Publ., 1954)

18. J.O. Long, ITIL 2011 At a Glance (Springer, New York, 2012). DOI: 10.1007/978-1-4614-3897-7.

19. A Guide to the Project Management Body of Knowledge (PMBOK Guide) (Project Management Institute Publ)

20. http://eltech.ru.

21. http://www.metodolog.ru. 